University of Nebraska - Lincoln

DigitalCommons@University of Nebraska - Lincoln

Faculty Publications: Department of Teaching, Department of Teaching, Learning and Teacher Learning and Teacher Education

Education

$2-2020$

\title{
The visual representation of dual language education
}

Theresa Catalano

Follow this and additional works at: https://digitalcommons.unl.edu/teachlearnfacpub

Part of the Bilingual, Multilingual, and Multicultural Education Commons, Curriculum and Instruction Commons, and the Teacher Education and Professional Development Commons

This Article is brought to you for free and open access by the Department of Teaching, Learning and Teacher Education at DigitalCommons@University of Nebraska - Lincoln. It has been accepted for inclusion in Faculty Publications: Department of Teaching, Learning and Teacher Education by an authorized administrator of DigitalCommons@University of Nebraska - Lincoln. 


\title{
The visual representation of dual language education
}

\author{
Theresa Catalano \\ University of Nebraska-Lincoln, USA \\ ORCID https://orcid.org/0000-0002-7519-030X
}

\begin{abstract}
Despite well documented benefits of dual language (DL) programs which deliver educational content in two languages, there are still few DL programs in the United States. As such, there is a need to understand how to effectively persuade more states/districts to adopt the programs. In addition, more critical research is needed that focuses on how the programs are represented visually, as well as how this visual representation reflects wider discourses about DL education that could impede the programs from reaching those who need them most. In this article, the author explores ideologies behind DL program discourse by looking at photojournalism (or in some cases, stock photos) from 34 local online news reports. She employed multimodal critical discourse analysis (MCDA), including a thematic analysis of images. Findings reveal that many of the discourses (e.g. neoliberalism) seen in analyses of written text were repeated visually but, in some cases, visual data communicated different discourses that were advanced in nuanced ways. The author concludes by urging more critical work in visual communication that focuses on educational issues.
\end{abstract}

Keywords: dual language education, multimodal critical discourse analysis (MCDA), visual communication

Published in Visual Communication 2020

DOI 10.1177/1470357220904395

Copyright (C) 2020 Theresa Catalano.

Published by SAGE Publications. Used by permission. 
ual language (DL) education is an umbrella term in the United States that refers to 'any program that provides literacy and content instruction to all students through two languages, and that promotes bilingualism and biliteracy, grade-level achievement, and multicultural competence for all students' (Howard et al., 2007: 1). DL programs were originally designed for students in the process of acquiring English as a form of social justice. That is, those Dual language (DL) education is an umbrella term in the United States that refers to 'any program that provides literacy and content instruction to all students through two languages, and that promotes bilingualism and biliteracy, grade-level achievement, and multicultural competence for all students' (Howard et al., 2007: 1). DL programs were originally designed for students in the process of acquiring English as a form of social justice. That is, those receiving instruction in English and their home language would have greater access to the academic content, and increase their chances of success. The programs were originally known as 'bilingual education', and then later rebranded as DL due to negative critique that they were not teaching English. This was connected to a growing English-only Americanization movement in the US, in which assimilationist perspectives and politics led to legislative initiatives in the early 2000 s that effectively banned bilingual pedagogies or use of languages other than English to instruct students in states such as California, Arizona, and Massachusetts (De Jong, 2013).

Much research in this area has shown that, if implemented correctly, including attending to the dynamics of race and power (Palmer, 2010), the programs can provide many benefits to students (see Cervantes-Soon, 2014, for an exhaustive list). Despite these benefits, there are comparatively few DL programs across the US, as opposed to similar programs in the rest of the world (Gross, 2016), and there is a need to understand how to effectively persuade more states/districts to select this model. In addition, critical research examining DL discourse has revealed ideologies that undermine the original purpose of the programs in the process of persuading stakeholders to adopt them. However, most of this research focuses on linguistic elements only. In addition, no research was found that studies the discourses put forth visually by local media outlets, which much of the public 
relies on to inform the way they think about educational issues (Howell, 2008; West et al., 2011).

As such, the aim of this article is to explore the ideology behind visual discourse on DL programs by looking at photojournalism (or in some cases, stock photos) from local online news reports. In order to do this, I incorporate multimodal critical discourse analysis (MCDA, see Machin and Van Leeuwen, 2016) to aid in connecting the visual representation of the programs to the way education is represented in the media in general. MCDA also helps us understand the way that discourses about DL programs connect to broader discourses circulating in society. The study is framed by the following research questions:

(1) How are DL programs represented visually in media discourse?

(2) How does this visual representation reflect wider discourses about language education and education in general?

\section{Media coverage of education}

Discourse, as it is used in this article, refers to meanings and values particular to institutions/social groups 'which are articulated in language in specific ways' (Kress, 1989: 6). A significant body of work currently exists that examines media discourse as it relates to education in general (and a smaller amount focuses on DL education discourse). I begin this discussion by justifying why we should analyze media discourse but also by showing how an understanding of media discourse of education generally can increase our understanding of visual communication about DL programs.

Educational scholars agree that news media play an important role in the formation of education policy (Gerstl-Pepin, 2002). Although many people learn about local schools through other means, many also 'rely on media outlets to inform their thinking about schooling more broadly' (Howell, 2008; West et al., 2011). News coverage of educational issues shapes which issues are deemed important as well as how we think about topics based on what is included, excluded, made salient, or left out, and what 
narratives/discourses are used to make sense of the new topics (Coe and Kuttner, 2018). In addition, because democracy relies on an informed and engaged public, media outlets play an important part in informing the public about policy issues such as education (Moses, 2007). Rather than working inside a vacuum, media are shaped by journalism standards and their institutions as well as the ideologies and narratives embedded by society at large (Coe and Kuttner, 2018; Fairclough, 2013[1995]; Van Dijk, 1988).

Research on the media's portrayal of education has found a common theme to be the 'discourse of derision' (Parker, 2011; Wallace, 1993), which blames schools for effects of systemic social inequities (Stack, 2006; Ulmer, 2016). Media outlets also project views of school reform that emphasize privatization and individual teacher accountability (Feuerstein, 2014; Hlavacik, 2016) while at the same time ignoring systemic challenges teachers face, such as heavy workloads and lack of resources (Thomas, 2006), which have been shown to have negative effects on education (Coe and Kuttner, 2018). Furthermore, a 'crisis frame', which portrays schools as being in a constant state of crisis or failure, dominates news coverage rather than emphasizing collective benefits or featuring solutions (O'Neil, 2012: 17). Finally, Pini (2011) examined websites for educational management organizations (the forprofit private companies that manage charter schools in the US). ${ }^{1}$ She found that they presented privatization as a magical solution to educational problems, masking their real 'for-profit nature' (pp. 268, 287).

\section{Discourses of dual language [DL] education}

Not surprisingly, themes similar to those described above also appear when examining the discourse about DL education. Valdez et al. (2016b) conducted a critical discourse analysis of Utah DL policy texts and found that already privileged groups were being targeted for the programs. Their analysis revealed the way in which DL discourse signaled gentrification trends (which connect to issues related to charter schools, see Allweiss et al., 2015). Gentrification used in this sense is a metaphor that compares inequity in multilingual language programs to the way urban districts are renovated to conform to middle-class tastes, often 
forcing current inhabitants to move from their homes to seek lower-cost housing elsewhere. In terms of DL programs, gentrification refers to the way these programs cater to the needs of affluent privileged students, often providing them with more access to the programs. The authors conclude by arguing that, if these trends are not attended to, they will lead to a broader pattern in US schools of 'inequitably distributed enrichment education' (Valdez et al., 2016b: 601).

In a related study, Freire et al. (2017: 286) examined promotional materials and policy documents related to Utah's DL programs, and found that the discourse positioned Latin $x^{2}$ as threatening to Whites. They also found that multilingualism was valued when it could also benefit dominant groups (e.g. interest convergence). Additionally, Coe and Kuttner (2018) found that bilingual education is a common topic in the coverage of race and ethnicity in education (usually relating to Spanish/English DL programs), but, interestingly, they note a recent increase in coverage of English-speaking students learning Mandarin. In contrast to the way that Spanish/English programs were covered to include issues of equality and connecting to immigration discourses, stories about English-speaking students learning Mandarin were situated in narratives that argued for the need to prepare students for a globalized world. They also note that 'the differential treatment of these two types of dual-language learning points to the racial undercurrents of bilingual education debates' (p. 10, see Spener, 1988).

Neoliberalism and its influence on DL programs were also found to be frequent topics in research. Freire et al. (2017: 278) define neoliberalism as 'a pattern of seeing all social phenomena through the lens of economic markets but without an emphasis on the inequalities that accompany all markets'. In the case of DL discourse, what is meant is an emphasis on the value of language learning for economic and business benefits. Valdez et al. (2016a: 849) studied the emergence of a shift in US language education policy discourses from an equity/heritage (EH) framework focused on equity for English learners and non-English heritage languages toward a 'global human capital (GHC)' framework linked to neoliberal considerations of the language skills of individuals and nations. Their findings indicate that media discourse has moved from 
focusing on language rights and community/heritage reasons for learning the language to the marketing of DL programs for economic and career reasons. Katznelson and Bernstein (2017) conducted a critical discourse analysis of the framing of bilingual education in California's Proposition 227, which eliminated bilingual education, and compared it to the framing of its appeal (Proposition 58), noting a similar, marked shift in the way that bilingual education was represented. Although Proposition 58 was passed and is hence worth celebrating, the authors cautioned against the way neoliberal and global human capital discourses were used to 'sell' multilingualism to voters, arguing for alternative discourses (p. 22).

\section{Conceptual framework}

\section{Photography and photojournalism}

The work of Susan Sontag (1973) is especially helpful when studying photography. According to Sontag, "photographs alter and enlarge our notions of what is worth looking at and what we have a right to observe' (p. 3), and they are just as much interpretations of the world as paintings and drawings. Because photographs capture a moment in time, they represent a thin slice of it. Therefore, 'they cannot create a moral position, but they can reinforce one - and can help build a nascent one' (p. 17). Sontag also points out that a camera's view of reality is more likely to hide more than it reveals.

Besides the work of Sontag, I draw on visual communication scholars such as Machin and Polzer (2015) and others that examine photography/photojournalism in various contexts. In their book Visual Journalism, Machin and Polzer found that good photojournalists create 'complex imagery' that symbolizes wider discourses (pp. 21, 23). In addition, they are interested in capturing moods and ideas while always keeping in mind where their work will be published. As such, photographs become just another design resource that can be used just like a layout or font. They also found that, because of the way the field of journalism has changed, photojournalists are increasingly sensitive to meeting the needs of news flows, values, and genres. Caple and Know (2015) document these changes in the field, noting how shrinking budgets have resulted 
in more organizations hiring citizen journalists, using stock images instead of hiring professional photographers, and print journalists being required to capture videos and images themselves.

In terms of scholarly work that demonstrates the power of photojournalism in shaping public opinion, Lutz and Collins (1991, 1993), help readers understand how images can challenge or comply with dominant discourses through their analysis of National Geographic photographs. Their description of the subject's gaze at the camera is particularly relevant to this study because the authors provide evidence that children, people of color, and the poor are more likely to be seen in frontal views in which they gaze back at the camera. They also posit that frontal views of subjects 'set the stage for either critique or celebration - but in either case evaluation - of the other as a person or type' (Lutz and Collins, 1991: 140). Other scholars have noted how the image can function to promote or conceal power interests and the importance of looking at the larger social contexts in which they are created and viewed (see Eagleton, 2007; Pink, 2005). Given the fact that very little scholarly work has analyzed visual data regarding DL education, it is clear that studying photojournalism in news reports has much to offer in terms of revealing ideologies about these programs that might not be easily seen in a linguistic analysis.

\section{Multimodal Critical Discourse Analysis (MCDA)}

This study employs MCDA, which includes concepts and theories from the fields of social semiotics and multimodality. Social semiotics aims to 'reveal how processes of meaning making (i.e. signification and interpretation or what is called semiosis) shape individuals and societies' (Jewitt et al., 2016: 58). The seminal work of Gunther Kress, Robert Hodge (e.g. Kress and Hodge, 1979), and Theo van Leeuwen (Kress and Van Leeuwen, 2006[1996]) laid the groundwork for this field, which was influenced by Hallidayan linguistics, semiotics, and critical linguistics (which later developed into critical discourse analysis or CDA). Multimodality, which emerged out of social semiotics in the 1990s, emphasizes that 'people use multiple means of meaning making' (Jewitt et al., 2016: 2 ), and that 'we need to attend to all semiotic resources being used to make a complete whole.' In MCDA, the sign is viewed as being 
motivated and having form, but also rooted in ideology and having a role in shaping 'the way the world appears to us' (Machin, 2016: 332). This means that paying attention to wider discourses is key, as well as what shapes the choice to use them and 'the way that political ideologies are infused into culture more widely' (Machin and Van Leeuwen, 2016: 243).

I utilized multiple tools from the above conceptual framework when looking at the data. For example, the concepts of modes (e.g. image, writing, layout, speech) and semiotic resources (a community's means of meaning making) are useful in achieving the aims of a multimodal analysis and therefore it is important to identify and describe them, and explain how they are used. This includes 'what motivates them, and how their in situ choices are shaped by (and realize) power' (Jewitt et al., 2016: 71). In addition, it is important to describe how the different modes interact and affect what each mode contributes to the communication (Bateman et al., 2017). In the case of this analysis, this means attending to the way the written text corresponds to the images and whether or not the image complements the text (or vice-versa) or contrasts it.

When looking at photographs, it is important to examine the semiotic resources of angle, distance, and gaze, which are always present in photographs and hence must be de-constructed (Van Leeuwen, 2008: 141). Camera angles (such as horizontal, downward, or upward) communicate power differences. In this way, downward angles signify symbolic power over someone, while upward angles communicate symbolic power over the viewer. Horizontal angles can convey involvement and a demand gaze (when the subject is looking directly at the viewer as if asking something of the viewer) or detachment and objectivization as in an offer image (when the subject is not engaging with the camera and, as such, the viewer becomes a type of 'voyeur'). In the same way, close-ups reveal reactions and expression, allowing viewers to observe their emotions (as in an Instagram selfie) or suggest claustrophobia or a threat, whereas long shots can make people appear anonymous and impersonal, presenting them as general characters (Ledin and Machin, 2018).

The difference between denotation (what the photograph documents) and connotation, which is how images communicate ideas 
and values (Barthes, 1977) is also essential to this analysis. Poses (including facial expressions), objects, clothing, and settings can all connote meaning. In addition, when context is taken out (e.g. the background is blurred, or generic so that it could be anywhere) and images become decontextualized, this can make the image symbolic (Lutz and Collins, 1993). Photographs 'not only represent what is going on, they also evaluate it, ascribe purpose to it, justify it, and so on, and in many texts these aspects of representation become far more important than the representation of the social practice itself ' (Van Leeuwen, 2008: 6). In representations of social practices, it is important to look for whether social actors are categorized as individuals, or collectively, as part of a cultural group that is then connected to positive or negative associations of this group in society.

Studying action processes that social actors engage in is also helpful in finding the underlying ideas and values communicated visually. For example, when people are shown doing material processes (e.g. attacking, defending) they are seen as having more agency or power in an event whereas when they are shown in mental (e.g. thinking) or behavioral processes (e.g. watching, listening), this conveys less agency or power, and emotional processes (e.g. smiling or crying) can connote feelings or moods (Ledin and Machin, 2018). In a critical analysis such as this, it is also important to look at who is not represented, or who is excluded from the representation. In the case of this analysis, I am especially concerned with which types of DL students (e.g. world language or heritage/maintenance) are present in images and which are not. I now turn to the method of analysis.

\section{Method}

\section{Data collection}

Data for this study was collected using the search terms 'dual language,' 'dual language immersion', or 'two-way immersion' for the time frame of 2018 only. This served to limit the data, but also to align with recent discourse trends (since this was the time period 
when analysis occurred). Criteria for selection of articles included the following: Articles must:

- be published in local news sources in 2018

- be between 200 and 2000 words

- contain images and written text

- report on DL programs

A total of 34 articles were found to fit the criteria. Although the images were the focus of analysis, in keeping with theories of multimodality, written text was also consulted during analysis in order to understand how the photographs were anchored in meaning, but also the affordances of the photographs in contrast to the linguistic elements in the articles.

\section{Data analysis}

Following Chouliaraki and Stolić (2019: 323), I conducted a thematic analysis of the photographs that appeared in the articles in order to show the 'range of visual variations that gravitated around' particular themes in the data. I determined themes by first uploading the articles to MAXQDA (1989-2019) qualitative software analysis program and conducting open coding of the images, attending to the written context in order to anchor multiple meanings of the photographs. In the second iteration of coding, I looked for anything I might have missed in the first coding, and categorized the previous codes into larger themes, labeling them with an extended thematic statement (e.g. identifying what a unit of data was about), which Saldana (2015: 175) refers to as 'themeing the data'. I then chose one or two examples of photographs that illustrated each theme to discuss in detail. In the Findings section below, I reveal the themes that emerged from the analysis (starting with the overarching theme of neoliberalism), using tools from MCDA mentioned above to describe, analyze, and connect them to the written discourse in the data, but also to the wider discourses of DL and education occurring during this time frame, and to the literature and theory described in previous sections. 


\section{Findings}

Neoliberal discourses were found to be present to some degree in most of the data of this analysis, which should not be surprising, given the literature review on media discourses of DL education. Hence, while the over-arching pattern of the data points to neoliberal discourses, I have categorized the three sub-themes as Vague and Outdated Clichés of Education, The Commodification of Diversity and Global Citizenship, and Prioritizing World Language Constituencies. ${ }^{3}$ However, keep in mind that each of the photographs illustrating these themes contains in some way the underlying and more enveloping theme of neoliberalism, which I explain in my analyses for each section.

\section{Vague and outdated clichés of education}

I found an overall pattern in the data in which many of the photos did not contribute much to understanding the main topics in the articles. For example, many photos were found of objects such as word charts or photos of buildings and cityscapes. In addition, those that attempted to portray education contained outdated ideologies. Figure 1 is a good example of both of these tendencies. This photo appears at the top of a local North Carolina

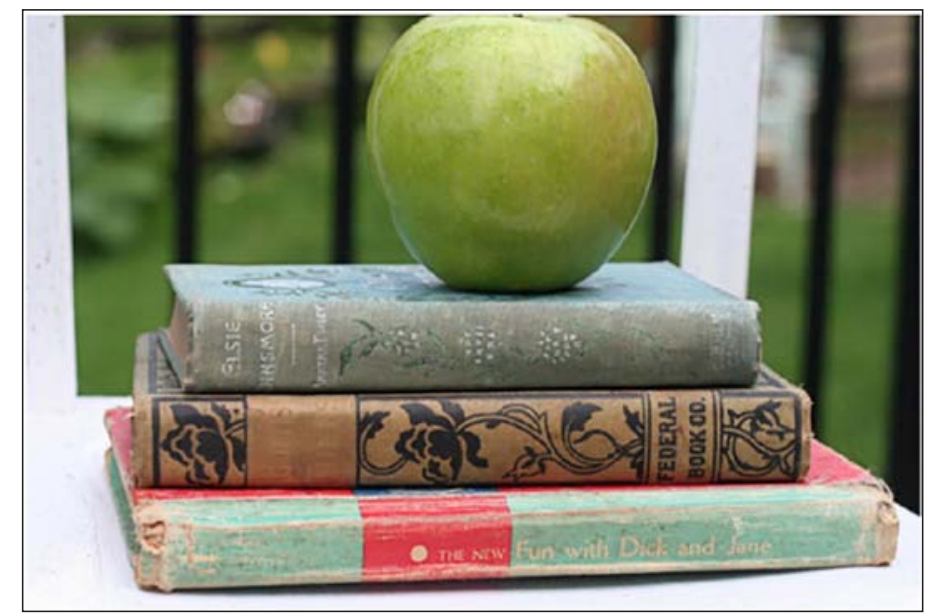

Figure 1. Guilford County Schools will be the second school system in the nation to have an Urdu-English dual language program. Source: Kate Ter Haar/ Creative Commons. Text 27: http://wunc.org/post/guilford-county-schoolsoffer-urdu-english-and-spanish-english-dual-language-programs\#stream/0 
public radio news website which announces that Guilford County Schools will be the second in the nation to offer an Urdu-English DL program along with Spanish-English programs.

This type of photo was typical in the data and, in describing and analyzing it, I am reminded of Sontag's (1973: 4) comment, 'Photographs, which package the world, seem to invite packaging.' In the case of this photo, the world of education is packaged up neatly in such a general way that it could be used over and over again for multiple purposes. In the photograph, three old and weathered books are stacked one on top of the other with a Granny Smith (green apple) on top and an out-of-focus background that appears to be a railing for some type of outdoor patio deck and the garden behind it. Upon closer examination, the books are revealed to be Elsie Dinsmore, an undecipherable title published by the Federal Book Company which existed between 1902 and 1904, and The New Fun with Dick and Jane. It is not clear what traditional (i.e. no longer used) classic reading books such as Elsie Dinsmore and Fun with Dick and Jane have to do with DL programs or current textbooks that students read today. Nonetheless, the worn-out and obviously old texts communicate 'tradition' or 'old-fashioned'. The same goes for the apple because it was originally used as payment for teachers in the late 1800 s, and then eventually came to symbolize education in general. Icons such as these remind us that photographs are 'cultural artefacts because its makers and readers look at the world with an eye that is not universal but tutored' (Lutz and Collins, 1993: xiii).

In terms of the origins of the photo, the credit reveals that it is a stock photo from Creative Commons. I performed a reverse image search (in which I pasted the image into Google Images) and found 28 other websites in which the photograph appeared, all of which were used to symbolically represent 'education' in some way. As Ledin and Machin (2018) have noted, stock photos such as these are guided by neoliberal principles that determine which photos sell best, not necessarily which photos are suitable for specific contexts. Machin and Van Leeuwen (2007) show how Getty Images align with corporate ways of thinking and capitalism, which reflects changes in the way photography is being used in mass media (e.g. to symbolize more than to document). 
Hansen and Machin (2008: 784) also found that Getty Images were made generic (which is the goal, so they can sell more) through decontextualization but also from the use of attributes (e.g. objects that symbolize things like the apple mentioned above) and generic settings.

Returning to Figure 1, it is clear how this photo was chosen to symbolize education in general. First, books are general icons for reading, which is a metonym for learning and school. The placement of the apple on top of the books solidifies that education is being signified since both symbols (at least in some cultural contexts) will be immediately recognized as standing for education. The decontextualization occurs through the out-of-focus background, with the green color of nature emitting an airy feeling of '"positive thinking" favored by contemporary corporate ideology' (p. 785). In addition, the blurriness of the background could signify a variety of educational settings such as a home (e.g. home schooling), or a school playground, or really anywhere, which is probably why it has been used so much for so many different educational contexts.

It is also easy to see why this photo was chosen for this article in particular: it discusses a program that has not yet begun (and so there are not opportunities to show what it is like visually), and because the idea of DL programs represents a complex and abstract concept, it was easier (and cheaper) to run a classic stock photo representing the generic idea of education. Unfortunately, this does nothing to help us understand the programs or promote any of the goals and aims of them, or to appeal to parents who might want to enroll their children in DL. Furthermore, the archaic books and symbols promote an old-fashioned idea of education that is not representative of what DL programs are or want others to perceive about them.

Figure 2 is another example of clichés of education as well as vagueness. The photo comes from an article about the growth of bilingual programs in Texas (San Marcos area) and it expresses concerns about a shortage of bilingual teachers.

Figure 2 depicts a teacher standing at the front of the room, pointing to a chart on the whiteboard. In front of the teacher and seated on the floor on a multi-colored carpet are 12 students 


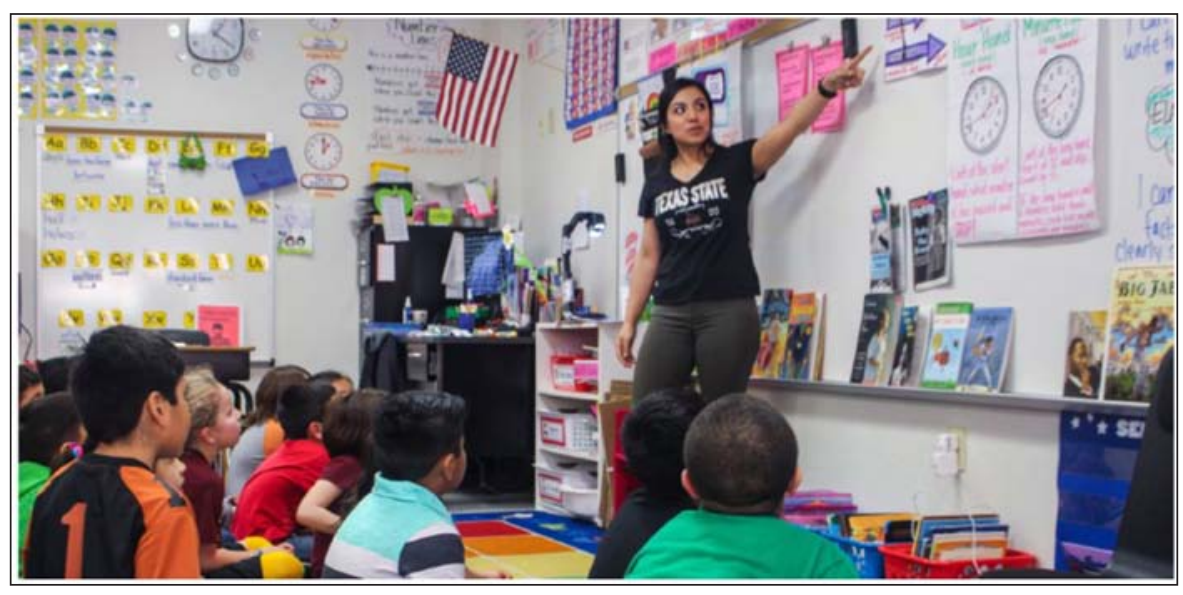

Figure 2. Source. Community Impact Newspaper. Reproduced with permission. Text 4: https://communityimpact.com/austin/san-marcos-buda-kyle/education/2018/03/19/hays-san-marcos-cisd-dual-language-programs-grow-officials-look-ways-around-bilingual-teacher-shortage/

(identified as second graders in the caption) who are looking at the teacher and the chart. The room is full of typical icons of educational settings such as word charts, bulletin boards, pictures, the alphabet, clocks, cubbies to store things like crayons, and various picture books. However, there is nothing in the photograph that further explains or illustrates the focus on teacher shortage in the article. Instead, Figure 2 is a typical large group photo that emerged in the data depicting Spanish-English programs (and occasionally French or Mandarin) which followed a similar pattern: a long-distance camera shot of the teacher pointing at something or writing on the board, students' backs to the camera, no gaze or direct engagement by the subjects with the viewer, and downward camera angles which indicate symbolic power over someone (Van Leeuwen, 2008). It projects a traditional image of a teacher as an authority figure because she is physically and symbolically above the students. In addition, it gives a vague portrayal of what is happening in the DL program (or what the district is doing to solve the teacher shortage problem).

According to Kaomea (2003), when looking at the visual, we must look at what is missing, erased, or replaced. In the case of Figure 2, there is no technology pictured (other than the whiteboard), no collaborative learning, and the photo shows a very teacher-centered approach which is less common in American 
schools today. That is, it depicts a generic and archaic idea of schooling that fits with reform movement discourse, falsely stating that education is not changing with the times and providing a convenient excuse to privatize schools (see Feuerstein, 2014; Hlavacik, 2016). While it does represent the moment that the photographer snapped the picture, by not presenting any other actions of the students before or after, it freezes them within this sole activity, leaving viewers with the image of old-fashioned school settings. Furthermore, there is nothing in the photograph that shows viewers anything special or specific about DL programs. The words are too small for readers to see if they are in different languages, and of course the subjects cannot be captured talking so we cannot see how well they speak or understand in two languages, or what they learn in DL programs. Because photographs are a 'thin slice of space and time' that encourage us to think about events in terms of memorable moments rather than complicated (and long) processes, we see the world of DL programs as a 'series of unrelated, free-standing particles' (Sontag, 1973: 2, 22, 2004). This image of the teacher pointing and students seated and listening merges well with traditional notions of what education is supposedly like, and hence does nothing to persuade or convince parents that they might like their child to be in the program. Moreover, because of the distance, the downward angle toward the students, the lack of gaze, and the fact that the children are pictured as part of a collective group of 'DL students', we are not invited to get to know them or engage with them. Instead, through similar hair, skin color, and poses they are homogenized as a particular type, that is, part of the cultural group of Latinx. As Van Leeuwen (2008: 144) notes, this type of categorization connotes 'the negative or positive values and associations attached' to this group, which, in the current political climate, has been largely discriminatory and negative.

It is also worth noting that, while many of the photographs in the data were similar to this one, there were also three individual, close-up shots of students. None of these were from Spanish/English programs, which would put forward a more positive impression. This finding aligns with Coe and Kuttner's (2018) work that notes a different type of coverage for Mandarin/English programs, and the way that topics differ between the two. That is, 
Mandarin/English programs tend to be within the topic of global citizenship whereas Spanish/English programs are featured in relation to immigration discourse and bilingual education debates.

\section{The commodification of diversity and global citizenship}

Overall, in portraying students in DL programs, the data revealed a very heterogenous group in which students of color were present in many of the images. Furthermore, in some cases, there seemed to be a purposeful featuring of students of color. Figure 3 features a girl in a Mandarin/English program and the written text that accompanies the photo (along with two other photos) describes new DL programs in New York.

Figure 3 is one of very few images found in which there is interaction with the viewer through the emotional process of smiling. Although the camera takes a slightly downward angle, the photo is a close-up, and conveys intimacy. In addition, the sweet smiling face of the girl (who is most likely not a heritage learner of Mandarin given her physical characteristics) through her direct gaze

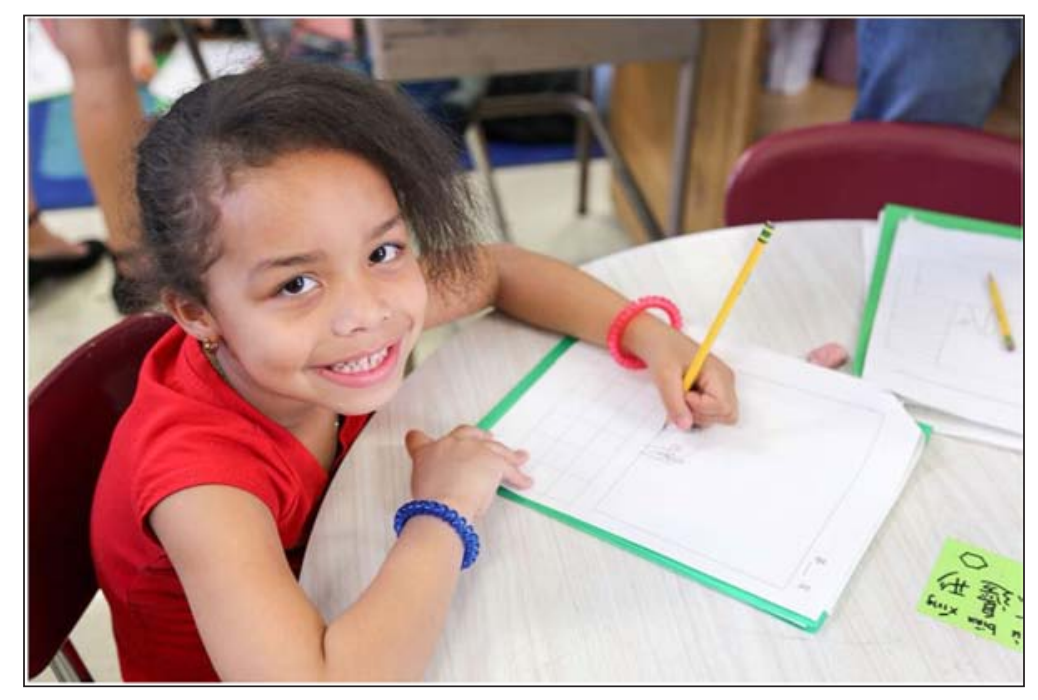

Figure 3. This student in Manhattan's P.S. 1 is learning both English and Mandarin as part of the school's Dual Language program. Source: NYC Department of Education. Reproduced with permission. Text 25: https://morningbellnyc.com/ wp-content/uploads/2018/05/1dc4b13a-c942-4490-a74b-70d12dd7fb21.jpg 
at the camera invites viewers to imagine their own children in a Mandarin program. Lutz and Collins (1991) noted this type of image to be more common among people (and especially children) of color particularly in terms of frontal views of subjects, which position them to be evaluated as a person or type.

Although advocates of DL programs certainly agree that showing students of color in images is important in drawing them to the programs, and this is an image that evokes positive perceptions, it is important to note that this is a Mandarin/English program and, as mentioned earlier, coverage seems to be qualitatively different than for Spanish/English programs. For example, in the coverage of Spanish/English programs only one close-up individual shot was found and one other close-up of a group of three students, while other images constituted larger groups. Moreover, although Spanish/English programs constitute the largest percentage of DL programs, they were underrepresented in the data, aligning with Pippert et al. (2013), who found that Hispanic students were under-represented in recruitment brochures. In contrast, Mandarin programs were over-represented in the data and two of the four close-up individual shots were from articles about these programs.

It is also interesting to compare the written text with the photo. The title of the article is 'DOE to Open More Bilingual Schools in Fall 2018', and the body of the text discusses the programs and lists where they will be in the district. In addition, it includes a quote from the Chancellor of the district that speaks to heritage/maintenance populations and the importance of maintaining and developing home languages. What is interesting is that, while this text emphasizes heritage/maintenance concerns across all new programs in the district, the three photographs in the article feature only Mandarin programs and only one of the images features a heritage speaker. In fact, Mandarin, French, Bengali, and Diné (Navajo) all have much fewer programs, but are represented visually more in the data than the percentage of programs that exist whereas Mandarin/Chinese is over-represented both visually and verbally, while Spanish (and French) are under-represented visually. This signifies a downplaying of Spanish/English programs as opposed to programs that are more frequented by world language 
constituencies such as Mandarin (with the exception of the Diné program). This is most likely because these programs are more rare or newer, which make them more newsworthy and it demonstrates Machin and Polzer's (2015) point about how photojournalists pay attention to news values and what sells. But, more interestingly, in the case of Mandarin, these programs often appear together with GHC narratives that target world language constituencies, and thus provide evidence of neoliberal narratives that emphasize globalization and marketization. This is because of business interests in China, and the way that corporations could benefit from more Mandarin-speaking employees. It also supports Coe and Kuttner's (2018) findings that global citizenship is a more common topic when Mandarin/Chinese programs are covered and that these programs receive more coverage in general.

According to Ahmed (2012: 78), similar to diversity, global citizenship is problematically seen as a 'set of skills that extends the global reach of individual subjects'. Fairclough (1999: 80) problematizes this view of education as 'key skills' which are seen as being easily transferred from one sphere of life to another, arguing that this can cause us to over-generalize and ignore local contexts and ways in which each context might need a different approach. Images are important in putting forth a narrative that programs are diverse, so much so that the representation of the diversity of an organization/program often becomes more important than the actual diversity in the program (Ahmed, 2012). In fact, studies such as Pippert et al. (2013) have shown a tendency for universities to represent themselves as more diverse than they actually are in brochures (which may remind readers of Van Leeuwen's, 2008, point about the representation becoming more important than the actual event/thing).

Essentially, images such as Figure 3, besides responding to criticism that the programs are not serving the needs of all students (see Figure 2, Text 26), are meant to be a type of interpellation that says 'hey you there' (Althusser, 1971: 163). If you look like her, you might want to be in this program or if you have a daughter like her, you should enroll her in this program. Moreover, the photo is effective in circulating the discourse that New York's school system is attending to 'diversity', which according to Puwar (2004), 
has come to mean including people who look different. Just like learning languages in order to be successful in a globalized world, diversity in the programs has become a commodity that can be 'sold' to prospective parents hoping to turn their children into 'global citizens' and, as a result, increase their chances of success. At the same time, this focus on world language constituencies de-emphasizes the written text's featuring of heritage/family reasons for learning languages.

\section{Prioritizing world language constituencies}

Discourses that targeted heritage/maintenance populations dominated the written texts of the data. It is possible that this occurred in part as a pushback to the current political climate led by Donald Trump in which racist rhetoric and policies position Latinx populations as criminal, illegal, and perpetually foreign and unwanted in the United States (Morales et al., 2019). However, this was not the case visually. Only a few images attempted to illustrate family/heritage reasons for DL. This is probably because images can evoke emotional responses to the programs which could cause a similar backlash to what happened in the '80s against bilingual programs when they were highly critiqued for not teaching English. As such, featuring White students in images can be a way of avoiding this backlash. Another reason is that it is harder to obtain photographs of family or abstract concepts such as heritage/ identity and this requires more time and effort.

Figure 4 illustrates this point. The photo depicts three children working on 'literacy activities' in an Illinois program, and announces the addition of a new two-way DL program. There is a White child in the center, supported on each side by a Latino boy and Latina girl. They all appear to be looking at something off camera to the bottom of the screen (probably a laptop since in the background of the photo another child is seated with a laptop and earphones). The White child in the center is the only one wearing earphones (and hence the only one hearing what all three are looking at). The girl has some kind of cards in her hand, and both the girl and boy are standing while the child in the center 


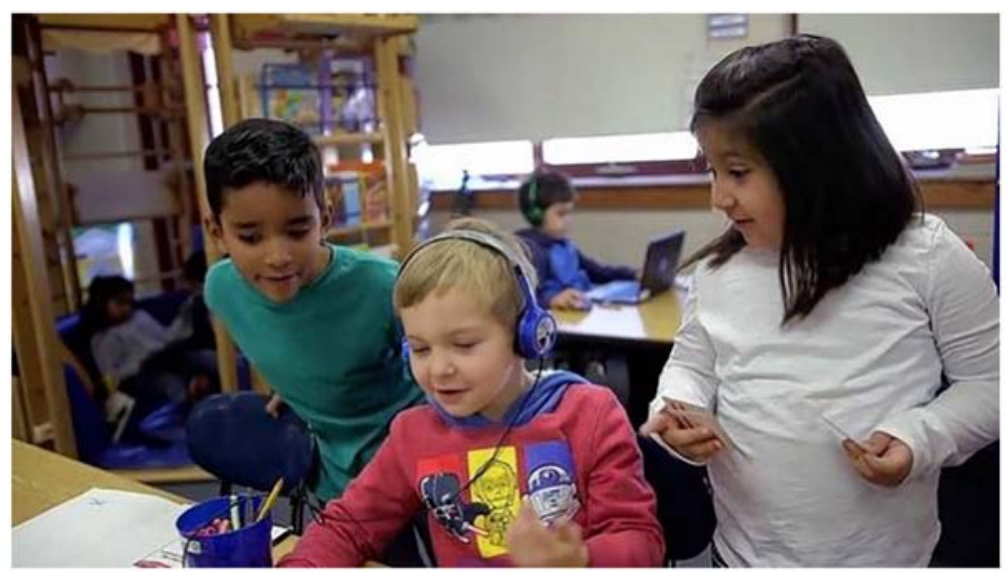

Figure 4. Students work on literacy activities in Jennifer Shamrylo's bilingual kindergarten classroom at Chesak Elementary School in Lake in the Hills. Huntley Community School District 158 this fall will launch a dual language program for kindergartners and first-graders at the school. Source: Daily Herald. Reproduced with permission. Text 17: http://www.dailyherald.com/news/20180309/ district-158-to-launch-dual-language-program-this-fall\#comments

is seated. The poses of the children (and the fact that the girl has some unrelated cards in her hand, probably from another activity she is engaged in) give the impression that they are passing by and have become interested in what the child in the center is doing.

The contents of the written text are also important to note in order to attend to contextual factors. For example, the article includes this quote from the district curriculum and instruction director: 'Our English-speaking families have been waiting for this initiative for a long time', she said, 'they are receiving dual language with open arms.' The quote reveals a targeting of world language (WL) constituencies (since heritage/maintenance communities are bilingual or do not speak English), and the photograph subtly elaborates (Barthes, 1967) the written text's emphasis on English-speaking families through the material processes and positioning of social actors in the photo. Not only is the White child shown in the center of the image, but he is engaged in the more active process of listening rather than just looking, as the other two Latinx students are doing. This is reminiscent of Valdés's (1997: 417) 'cautionary note' in which she points out how reporters writing a story on DL programs often concentrate on how well English-speaking children are learning Spanish while 'ignoring how 
well a Spanish-speaking child is learning English'. Figure 4, with the more active White child as the centerpiece appears to be a visual representation of the same phenomenon. Hence, this photo (and others found in the data) which subtly highlight White children in the programs, provide evidence of gentrification, something that Valdés warned of already in 1997, and mirror the phenomena noted in the research of written discourse. Thus, although the data demonstrates a very diverse student body in the programs, and does focus attention on students of color, there are subtle and nuanced ways in which the visual prioritizing of English-speaking families (e.g. world language constituencies) occurs at the same time.

\section{Discussion /conclusion}

Findings revealed an overall vague visual representation of what DL is and what students and teachers actually do in these programs. This projects an archaic and generic view of education that is reminiscent of the way typical media outlets have represented educational issues as old, and in need of reform (hence privatization is the remedy!). Evidence of the commodification of diversity and its connection to global citizenship was shown by images of Mandarin programs and the way that they are marketed to world language constituencies as part of becoming prepared for a global society. Additionally, although there was attention paid visually to students of color in the programs, there were also nuanced ways in which English-speaking families (aka White students) were prioritized visually. In the process of focusing on the English-speaking families or students of color in Mandarin programs, the needs of heritage/maintenance communities were backgrounded.

Some of the images can be attributed to reactions to an overall hostile climate for immigrants, and because DL heritage/ maintenance communities are children of immigrants, focus on these students brings out the same anti-immigrant sentiment by readers/viewers (see Lu and Catalano, 2015). In order to avoid the backlash to the news sources (and by default, the programs themselves), journalists take the safe route, focusing individual 
attention on world language students and using global citizenship as a primary reason to advocate for the programs (as opposed to the needs of heritage learners).

What is also clear from patterns in the data is that photojournalists 'don't necessarily work to document reality but rather to sell images' (Machin and Polzer, 2015: 45). Since news sources are corporations, it is fitting that they are governed by corporate ideologies that position profit and market needs first. Large group long shots, which do not do service to the innovation and benefits of the programs or help understand what goes on in them, point to a lack of resources or time for journalists (see Caple and Know, 2015; Machin and Polzer, 2015). They often then resort to long shots that can be taken quickly or stock photos as a more efficient way of representing the issues (Machin and Van Leeuwen, 2007).

Although the findings are based on media discourse, as opposed to materials put out by the programs themselves, they still hold important implications for DL advocates and stakeholders. First, visual media discourse reproduces dominant ideologies about DL programs and the people in them. In this case, neoliberal ideologies that value profit and economic concerns were found visually (e.g. use of stock photos, prioritizing of world language constituencies for reasons of global citizenship) just as in linguistic elements of discourse discussed in the research. In addition, ideologies that commodify diversity as a way of marketing the programs were shown through the highlighting of close-up photos of students of color. At the same time, equity-heritage discourses were ever-present in written texts, particularly in regards to Spanish/ English programs, but less present in images, where very few photos connected them visually to family or heritage.

However, just as images can represent ideologies, they can be used to shape or change them. Albeit administrators/program directors do not ultimately have control over the images that are published in the media, they can make efforts to improve the visual representations of their programs by offering images to journalists that inquire about the programs, or allowing journalists to come to events in which children are practicing their bilingualism with family and community members, etc. Moreover, they can control their own visual discourse about the 
programs (such as brochures). Hence, this analysis can inform them how to create promotional materials that attract parents to the programs but still put forth multicultural and multilingual discourses that center the needs of heritage/maintenance populations because they are the ones who stand to benefit most. Finally, critically appraising how we choose to dispense our visual resources (Shankar, 2014: 349) may keep us from recreating new problems while we try to solve old ones. As such, I call for more visual communication scholars to tackle visual media coverage of education, and to view themselves and their research as agents in developing, recontexualizing and re-enacting new discourses (Fairclough, 2011).

Acknowledgments - The author would like to thank the panel participants, discussant, and audience at the American Educational Research Association annual meeting in Toronto (2019) for their useful insights and recommendations on an earlier draft of this article. In addition, heartfelt thanks goes to Emily Suh, Amanda Morales, and David Machin for their careful and thoughtful feedback, and to students in 930M multimodal analysis doctoral seminar for their comments on a later draft. Finally, many thanks to the anonymous reviewers and editor of Visual Communication for their incredibly helpful suggestions all of which I believe contributed to making the article better.

Funding - The author received no financial support for the research, authorship, and publication of this article. There is no conflict of interest.

\section{Notes}

1. In the US, 'charter schools' (some of which are for-profit) are K-12 schools that have fewer regulations than public (state) schools but still receive some public funding.

2. 'Latinx' is used to refer to people of Latin American backgrounds using the ' $x$ ' ending to signify gender inclusivity and challenge binary notions of gender in solidarity with transgender and gender non-conforming members of our community (Martínez et al., 2017).

3. World language constituencies refer to students who study the language as a foreign language, not as a language they speak at home or in their community. 


\section{References}

Ahmed S (2012) On Being Included: Racism and Diversity in Institutional Life. Lanham, MD: Duke University Press.

Allweiss A, Grant CA and Manning K (2015) Behind the photos and the tears: Media images, neoliberal discourses, racialized constructions of space and school closings in Chicago. Race Ethnicity and Education 18(5): 611-631.

Althusser L (1971) Lenin and Philosophy and Other Essays, trans. B Brewster. London: New Left Books.

Barthes R (1967) Elements of Semiology. London: Cape.

Barthes R (1977) Image-Music-Text. London: Fontana.

Bateman J, Wildfeuer J and Hiippala T (2017) Multimodality: Foundations, Research and Analysis: A Problem-Oriented Introduction. Berlin: Walter de Gruyter.

Caple H and Knox JS (2015) A framework for the multimodal analysis of online news galleries: What makes a 'good' picture gallery? Social Semiotics 25(3): 292-321.

Cervantes-Soon CG (2014) A critical look at dual language immersion in the New Latin@ diaspora. Bilingual Research Journal 37(1): 64-82. DOI: 10.1080/15235882.2014.893267.

Chouliaraki L and Stolić T (2019) Photojournalism as political encounter: Western news photography in the 2015 migration 'crisis'. Visual Communication. DOI: 10.1177/1470357219846381.

Coe K and Kuttner PJ (2018) Education coverage in television news: A typology and analysis of 35 years of topics. AERA Open 4(1). DOI: $10.1177 / 2332858417751694$.

De Jong EJ (2013) Policy discourses and US language in education policies. Peabody Journal of Education 88(1): 98-111.

Eagleton T (2007) Ideology: An Introduction. London: Verso.

Fairclough N (1999) Global capitalism and critical awareness of language. Language Awareness 8(2): 71-83.

Fairclough N (2011) Semiotic aspects of social transformation and learning. In: Rogers R (ed.) An Introduction to Critical Discourse Analysis in Education, 2nd edn. Mahwah, NJ: Lawrence Erlbaum, 119-127.

Fairclough N (2013[1995]) Critical Discourse Analysis: The Critical Study of Language, 2nd edn. London: Routledge.

Feuerstein A (2014) News framing and charter school reform. Critical Education 5(17): 1-30.

Freire JA, Valdez VE and Delavan MG (2017) The (dis)inclusion of Latina/o interests from Utah's dual language education boom. Journal of Latinos and Education 16(4): 276-289.

Gerstl-Pepin CI (2002) Media (mis)representations of education in the 2000 presidential election. Educational Policy 16(1): 37-55. DOI: 10.1177/0895904802016001003. 
Gross N (2016) Dual-language programs on the rise across U.S. In: Education Writers Association. Available at: https://www.ewa.org/blog-latinoedbeat/dual-language-programs-rise-across-us (accessed 2 July 2019).

Hansen A and Machin D (2008) Visually branding the environment: Climate change as a marketing opportunity. Discourse Studies 10(6): 777-794.

Hlavacik M (2016) Assigning Blame: The Rhetorical of Education Reform. Cambridge, MA: Harvard Education Press.

Howard ER et al. (2007) Guiding Principles for Dual Language Education. Washington, DC: Center for Applied Linguistics.

Howell W (2008) Education policy, academic research, and public opinion. In: Hess F (ed.) When Research Matters: How Scholarship Influences Education Policy. Cambridge, MA: Harvard Education Press, 135-153.

Jewitt C, Bezemer J and O'Halloran K (2016) Introducing Multimodality. London: Routledge.

Kaomea J (2003) Reading erasures and making the familiar strange: Defamiliarizing methods for research in formerly colonized and historically oppressed communities. Educational Researcher 32(2): 14-23.

Katznelson N and Bernstein KA (2017) Rebranding bilingualism: The shifting discourses of language education policy in California's 2016 election. Linguistics and Education 40: 11-26.

Kress G (1989) Linguistic Processes in Sociocultural Practice. Oxford: Oxford University Press.

Kress GR and Hodge RIV (1979) Language as Ideology. London: Routledge.

Kress GR and Van Leeuwen T (1996) Reading Images: The Grammar of Visual Design. Hove: Psychology Press.

Ledin P and Machin D (2018) Doing Visual Analysis: From Theory to Practice. London: Sage.

Lu J and Catalano T (2015) Let them learn English: Reader response to media discourse about dual language education. International Journal of Language Studies 9(2): 1-24. •

Lutz C and Collins J (1991) The photograph as an intersection of gazes: The example of National Geographic. Visual Anthropology Review 7(1): 134-149.

Lutz C and Collins J (1993) Reading National Geographic. Chicago: Chicago University Press.

Machin D (2016) The need for a social and affordance-driven multimodal critical discourse studies. Discourse \& Society 27(3): 322-334.

Machin D and Polzer L (2015) Visual Journalism. New York: Macmillan International Higher Education.

Machin D and Van Leeuwen T (2007) Global Media Discourse: A Critical Introduction. New York: Routledge.

Machin D and Van Leeuwen T (2016) Multimodality, politics and ideology. Journal of Language and Politics 15(3): 243-258. 
Martínez RA, Durán L and Hikida M (2017) Becoming 'Spanish learners': Identity and interaction among multilingual children in a Spanish- English dual language classroom. International Multilingual Research Journal 11(3): 167-183. DOI: 10.1080/19313152.2017.1330065.

Morales A, Abrica E and Herrera S (2019) Manana complex: A revelatory narrative of teachers' white innocence and racial disgust toward Mexican-American children. The Urban Review 302: 1-24. DOI: 10.1007/ s11256-019-00499-1.

Moses MS (2007) The media as educators, educational research, and autonomous deliberation. Peabody Journal of Education 82(1): 150-165.

O'Neil M (2012) Overarching Patterns in Media Coverage of Education Issues: A Core Story of Education Report. Washington, DC: FrameWorks Institute.

Palmer D (2010) Race, power, and equity in a multiethnic urban elementary school with a dual-language 'strand' program. Anthropology and Education Quarterly 41(1): 94-114.

Parker WC (2011) Constructing public schooling today: Derision, multiculturalism, nationalism. Educational Theory 61: 413-432. DOI:10.1111/j.1741-5446.2011.00412.x.

Pini M (2011) The discourses of education management organizations: A political design. In: Rogers R (ed.) An Introduction to Critical Discourse Analysis in Education, 2nd edn. London: Routledge, 267-291.

Pink S (2011) Images, senses and applications: Engaging visual anthropology. Visual Anthropology 24(5): 437-454.

Pippert TD, Essenburg LJ and Matchett EJ (2013) We've got minorities, yes we do: Visual representations of racial and ethnic diversity in college recruitment materials. Journal of Marketing for Higher Education 23(2): 258-282.

Puwar N (2004) Space Invaders: Race, Gender and Bodies out of Place. Oxford: Berg.

Saldana J (2015) The Coding Manual for Qualitative Researchers. New York: Sage.

Shankar A (2014) Towards a critical visual pedagogy: A response to the 'end of poverty' narrative. Visual Communication 13(3): 341-356.

Sontag S (1973) On Photography. London: Allen Lane.

Sontag S (2004) Regarding the Pain of Others. London: Picador.

Spener D (1988) Transitional bilingual education and the socialization of immigrants. Harvard Educational Review 58(2): 133-154.

Stack M (2006) Testing, testing, read all about it: Canadian press coverage of the PISA results. Canadian Journal of Education/Revue canadienne de l'éducation 29(1): 49-69.

Thomas S (2006) Education Policy in the Media: Public Discourses on Education. Teneriffe, Queensland: Post Pressed.

Ulmer JB (2016) Re-framing teacher evaluation discourse in the media: An analysis and narrative-based proposal. Discourse: Studies in the Cultural Politics of Education 37(1): 43-55. 
Valdés G (1997) Dual language immersion programs: A cautionary note concerning the education of language-minority students. Harvard Educational Review 67(3): 391-429.

Valdez VE, Delavan G and Freire JA (2016a) The marketing of dual language education policy in Utah print media. Educational Policy 30(6): 849- 883.

Valdez VE, Freire JA and Delavan MG (2016b) The gentrification of dual language education. Urban Review 48(4): 601-627.

Van Dijk TA (1988). News as Discourse. New York, NY: Routledge.

Van Leeuwen T (2008) Discourse and Practice: New Tools for Critical Discourse Analysis. Oxford: Oxford University Press.

Wallace M (1993) Discourse of derision: The role of the mass media within the education policy process. Journal of Education Policy 8(4): 321-337.

West DM, Whitehurst GJ and Dionne EJ Jr (2011) Americans Want More Coverage of Teacher Performance and Student Achievement. Washington, DC: Brookings Institution.

\section{Corpus}

Text 1: https://www.mv-voice.com/news/2018/05/21/ report-dual-immersion-leaves-students-behind

Text 2: https://www.chalkbeat.org/posts/ny/2018/05/03/new-york-cityto-add-50-bilingual-programs-the-latest-in-a-push-to-help-english-learners /

Text 3: http://newsroom.ocde.us/garden-grove-unified-to-open-a-secondspanish-dual-language-program-in-2018-19/

Text 4: https://communityimpact.com/austin/san-marcos-buda-kyle/education/2018/03/19/hays-san-marcos-cisd-dual-language-programs-grow-officials-look-ways-around-bilingual-teacher-shortage/

Text 5: https://www.wfyi.org/news/articles/ educators-say-more-guidance-needed-for-dual-language-programs

Text 6: http://www.chicagotribune.com/suburbs/elmhurst/news/ct-elhd205-dual-language-tl-0118-20180110-story.html

Text 7: http://www.rockymounttelegram.com/News/2018/05/10/Dual-language-program-set-to-expand.html

Text 8: https://www.newamerica.org/education-policy/edcentral/ dualimmersion-equity/

Text 9: http://www.news-gazette.com/news/local/2018-04-07/urbana-districts-dual-language-program-looking-expand.html

Text 10: http://www.cms.k12.nc.us/News/Pages/Expansion-of-populardual-language-program.aspx 
Text 11: https://wcfcourier.com/news/local/education/waterloo-schoolsdual-language-immersion-program-to-expand/article_da82b5b31245-56c4-bad2-82788603c376.html

Text 12: https://www.daily-times.com/story/news/local/farmington/2018/04/03/two-farmington-schools-offer-dual-languageclasses-kindergartners/481952002/

Text 13: https://www.timesrecord.com/articles/front-page/ brunswick-speaks-of-dual-language-benefits /

Text 14: https://qns.com/story/2018/05/04/dozen-queens-public-schoolswill-expanded-bilingual-education-starting-fall/

Text 15: https://www.thebostonpilot.com/article.asp?ID=182118

Text 16: https://www.austinisd.org/announcements/superintendentspeaks-sxswedu-panel-about-benefits-importance-dual-language

Text 17: http://www.dailyherald.com/news/20180309/ district-158-to-launch-dual-language-program-this-fall\#comments

Text 18: https://www.timesledger.com/stories/2018/21/ bengaliprogram_2018_05_25_q.html

Text 19: https://jacksonheightspost.com/city-to-add-bilingual-languageprograms-at-14-queens-schools-this-fall

Text 20: https://www.chalkbeat.org/posts/ny/2018/01/17/new-york-citywill-add-dual-language-options-in-pre-k-to-attract-parents-andencourage-diversity/

Text 21: http://www.cleburnetimesreview.com/news/cisd-to-hold-meetingon--way-dual-language-program/article_fafof004-fd6a-11e7-aa16eb445827cf26.html

Text 22: http://www.coastalview.com/news/dli-expansion-proposal-spurscontroversy/article f98eacc8-3f56-11e8-9862-dfa979d0ca62.html

Text 23: https://qns.com/story/2018/01/18/city-adds-new-dual-languagepre-k-programs-6-queens-neighborhoods/

Text 24: https://communityimpact.com/austin/leander-cedar-park/editorspick/2018/05/24/leander-isd-expands-two-way-dual-languageprogram-to-new-schools-as-demand-rises/

Text 25: https://morningbellnyc.com/wp-content/ uploads/2018/05/1dc4b13ac942-4490-a74b-70d12dd7fb21.jpg

Text 26: https://www.scpr.org/news/2018/01/18/79893/ the-kids-in-lausd-who-most-need-dual-language-inst/

Text 27: http://wunc.org/post/guilford-county-schools-offer-urdu-englishand-spanish-english-dual-language-programs\#stream/0

Text 28: https://riograndeguardian.com/dual-language-program-is-makingmcallens-sanchez-elementary-popular/ 
Text 29: http://www.mysuburbanlife.com/2018/01/11/dual-languageto-begin-at-conrad-fischer-in-elmhurst-next-school-year/ aa5boit/

Text 30: http://www.wfae.org/post/cms-turns-dual-language-programsclose-education-gaps\#stream/0

Text 31: http://www.highgroundnews.com/features/duallanguage.aspx

Text 32: https://therivardreport.com/ saisd-will-triple-its-dual-language-programs-in-2018-19/

Text 33: http://www.newsoforange.com/education/article_3c2292f4-9b4911e8-a256-af9of2de6fa1.html

Text 34: https://fremonttribune.com/news/local/education/washingtonelementary-s-dual-language-program-looks-to-expand/article ebf28334-7d60-5eaf-ab7c-0e7219bca463.html

\section{The Author}

Theresa Catalano is currently Associate Professor of Second Language Education/Applied Linguistics at the University of Nebraska-Lincoln. Her research focuses on multimodal critical discourse analysis, language education, and education and migration. Address: Department of Teaching, Learning and Teacher Education, University of Nebraska-Lincoln, Henzlik 118, Lincoln, NE 68588, USA. email tcatalano2@unl.edu 